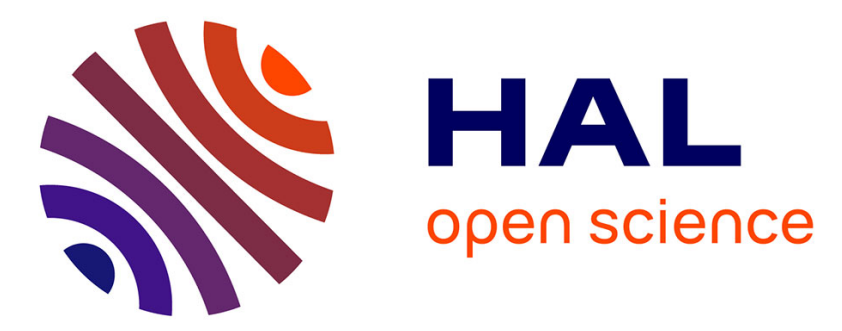

\title{
Electric charge trapping, residual stresses and properties of ceramics after metal/ceramics bonding
}

Lamine Hattali, Nadir Mesrati, Daniel Tréheux

\section{To cite this version:}

Lamine Hattali, Nadir Mesrati, Daniel Tréheux. Electric charge trapping, residual stresses and properties of ceramics after metal/ceramics bonding. Journal of the European Ceramic Society, 2012, 32, pp.717-725. hal-00657384

\section{HAL Id: hal-00657384 \\ https://hal.science/hal-00657384}

Submitted on 6 Jan 2012

HAL is a multi-disciplinary open access archive for the deposit and dissemination of scientific research documents, whether they are published or not. The documents may come from teaching and research institutions in France or abroad, or from public or private research centers.
L'archive ouverte pluridisciplinaire HAL, est destinée au dépôt et à la diffusion de documents scientifiques de niveau recherche, publiés ou non, émanant des établissements d'enseignement et de recherche français ou étrangers, des laboratoires publics ou privés. 


\title{
Electric charge trapping, residual stresses and properties of ceramics after $\mathrm{metal} /$ ceramics bonding
}

\author{
M.L. Hattali ${ }^{a, *}$, N. Mesrati ${ }^{b}$, D. Tréheux ${ }^{a}$ \\ ${ }^{a}$ Laboratoire de Tribologie et Dynamique des Systèmes, UMR CNRS ECL ENISE ENSMSE 5513, École Centrale de Lyon, 69134 Ecully cedex, France \\ ${ }^{\mathrm{b}}$ Laboratoire de Sciences et Génie des Matériaux, École Nationale Polytechnique d'Alger, 10, avenue de Hassen Badi EL harrach Alger, Algeria
}

\begin{abstract}
The use of ceramic components in electrical engineering and mechanical applications is rapidly increasing. Most of these applications require the use of ceramics bonded with metal. In this paper, we have studied the role of residual stresses occurring after joining between an industrial alumina ceramic $\left(\mathrm{Al}_{2} \mathrm{O}_{3}\right)$ and Ni-based super-alloy, on the dielectric behaviour of ceramics. The electric charging phenomenon i.e. trapping-detrapping or diffusion of electric charges is studied by Scanning Electron Microscope Mirror Effect (SEMME) coupled with the Induced Current Method (ICM). Knowing that localized trapped charges in ceramics is a source of damage, the correlation between residual stress intensity, apparent-toughness of ceramics and ability to trap charges near the interface was demonstrated: the SEMME and ICM measurements of the quantities of trapped charges near the interface, highlighted the changes in the ceramic properties related to residual stresses due to both thermo-mechanical effect and diffusion of metallic species in the ceramics, during the bonding process.
\end{abstract}

Keywords: Joining; Toughness; Residual stress; $\mathrm{Al}_{2} \mathrm{O}_{3}$; Dielectric properties

\section{Introduction}

Ceramics are potentially interesting for industrial application under severe conditions of service. Their insulating properties, wear resistance and high melting point make them attractive. But it is sometimes difficult to use ceramic materials as general structural materials because they have some fatal weakness in impact resistance, toughness, or during manufacturing process.

However, in order to be used more effectively, ceramics can be joined to metals. In this context, joining of ceramic has been the subject of numerous researches, essentially focused on solid state bonding, ${ }^{1-3}$ direct copper bonding technique $(\mathrm{DCB})^{4,5}$ and active metal brazing, whose feasibility has been demonstrated. ${ }^{6,7}$ The reader is referred to the numerous references reported in our previous papers. ${ }^{1-3,8}$ In general, ceramics

\footnotetext{
* Corresponding author. Present address: CEA, IRAMIS, SPCSI, Group Complex Systems and Fracture, 91191 Gif sur Yvette, France. Tel.: +33 472186517; fax: +33478331140 .

E-mail addresses: hattali.lamine@gmail.com, hatlam69_2@hotmail.com (M.L. Hattali).
}

and metals are joined at high temperature. Residual stresses appear in the joint during the cooling process according to the plastic and elastic properties of both materials. These stresses influence the strength and fracture toughness of the bond. ${ }^{1-3}$ The stress-field depends of many factors, e.g. thermo-mechanical properties of both material (temperature dependence of mechanical characteristics, thermal expansion coefficients), thermal cycle used, geometric design ${ }^{1,3,8,9}$ and also electrical charge generation occurring during contact, diffusion and friction. . $^{10,11}$

The breakdown of insulators, ${ }^{12,13}$ also the tribology (friction coefficient, wear) ${ }^{10,11}$ and the fracture of ceramics ${ }^{14}$ were explained on the basis of the concept of the space charge physics. ${ }^{12,15}$ According to this approach and knowing that a localized trapping of charges on structural defect (point defects, dislocations, grain boundaries, and more generally interfaces) is a source of damage, the properties (toughness, friction, wear mechanical, breakdown strength) of insulating materials (ceramics, polymers, composites) can be explained in a new way. ${ }^{12}$

In order to understand the reasons of ceramic damage when there are joined to metal, we proposed to study the trapping and/or diffusion of charges i.e. the storage and/or dissipation 


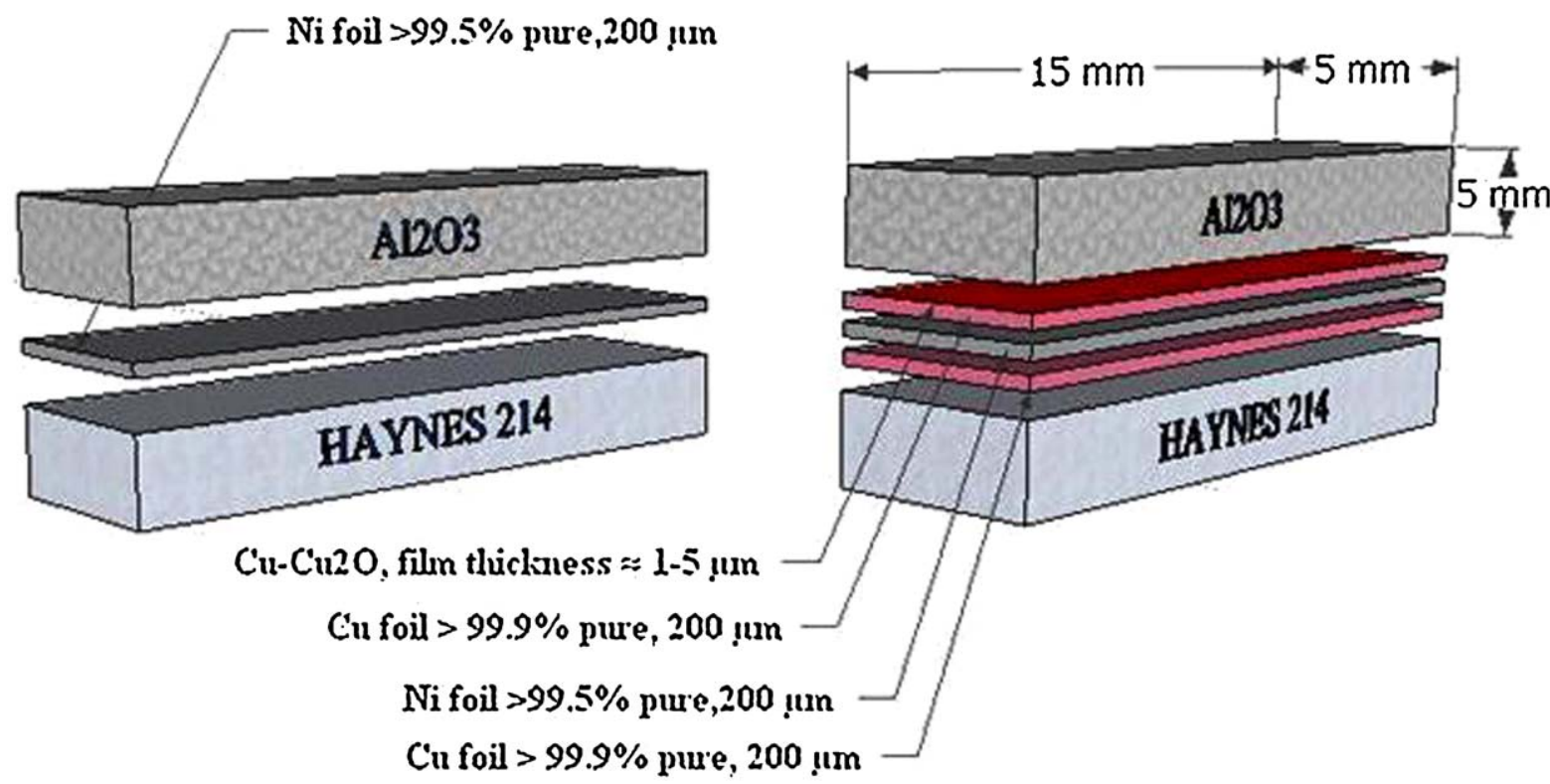

Fig. 1. Schematic illustration of a $\mathrm{Al}_{2} \mathrm{O}_{3} / \mathrm{HAYNES}^{\circledR} 214^{\mathrm{TM}}$ joint (a) with Ni interlayer; (b) with $\mathrm{Cu} 2 \mathrm{O}-\mathrm{Cu} / \mathrm{Ni} / \mathrm{Cu}$ interlayer.

of polarization energy into alumina materials, close to the metal-ceramic interface, according to the concept of the space charge physics. Previously, the residual stresses expected in $\mathrm{Al}_{2} \mathrm{O}_{3} / \mathrm{Ni} / \mathrm{HAYNES}^{\circledR} 214^{\mathrm{TM}}$ joints were characterized mechanically and simulated using Vickers indentation method (VIF), X-ray diffraction (XRD) and Finite Element Analysis (FEA). ${ }^{1}$ It was proved that fracture strength of the joint and apparenttoughness of alumina decrease near the metal-ceramic interface due to tensile residual stresses developed close to the interface. (The term apparent-toughness has been used rather than toughness, to show that the measures correspond to the superposition of several effects.)

In this study, the Scanning Electron Microscope Mirror Effect (SEMME) ${ }^{16}$ and Induced Current Method (ICM) ${ }^{17}$ were used to determine the quantity of charges trapped in ceramics. This work was the first attempt to apply the SEMME techniques to metal-ceramic joints. The results show the correlation between ceramic apparent-toughness, intensity of residual stresses and the capacity of charges to trap near the metal-ceramic interface. $\mathrm{Al}_{2} \mathrm{O}_{3} / \mathrm{Ni} / \mathrm{HAYNES}^{\circledR} 214^{\mathrm{TM}}$ and $\mathrm{Al}_{2} \mathrm{O}_{3} / \mathrm{Cu} / \mathrm{Ni} / \mathrm{Cu} / \mathrm{HAYNES}^{\circledR} 214^{\mathrm{TM}}$ systems were considered as model for metal-ceramic joint.

\section{Experimental procedure}

\subsection{Materials}

As in the previous study, ${ }^{1,3,8}$ the ceramic material used in this work is a commercial polycrystalline $\alpha-\mathrm{Al}_{2} \mathrm{O}_{3}$ (AL23 alumina), from UMICORE Marketing services. The metal is the nickel super alloy (HAYNES ${ }^{\circledR} 214^{\mathrm{TM}}$ ), which is widely used in technological applications at high temperatures and in severe chemical atmosphere such as that encountered in industrial heating market (petrochemical, etc.). For bonding, both base material blocks were cut into small pieces with the dimension
$15 \mathrm{~mm} \times 5 \mathrm{~mm} \times 5 \mathrm{~mm}$. The pure metal foils used as filler materials were commercially available and of high purity. Both $\mathrm{Ni}$ and $\mathrm{Cu}$ foils were prepared by cold rolling down to a thickness of $200 \mu \mathrm{m}$ and $100 \mu \mathrm{m}$ respectively and had the same dimensions as the ceramics and alloy blocks (Fig. 1).

Prior to bonding, the faying surfaces of HAYNES ${ }^{\circledR} 214^{\mathrm{TM}}$ and alumina were well polished. The $R_{\mathrm{a}}$ surface roughness of HAYNES ${ }^{\circledR} 214^{\mathrm{TM}}$ and alumina was equal respectively to 0.08 and $0.48 \mu \mathrm{m}$. All surfaces of base materials were cleaned by immersion in acetone with ultrasonic agitation for $0.5 \mathrm{~h}$. The $\mathrm{Al}_{2} \mathrm{O}_{3} / \mathrm{Ni} / \mathrm{HAYNES}^{\circledR} 214^{\mathrm{TM}}$ system was fabricated by solid state bonding ${ }^{1,3}$ at $1150^{\circ} \mathrm{C}$ for $1 \mathrm{~h}$. A pressure of $16 \mathrm{MPa}$ was applied through a pneumatic piston. Heating speed was $150^{\circ} \mathrm{C} / \mathrm{h}$ and cooling speed was $200^{\circ} \mathrm{C} / \mathrm{h}$. The solid state bonding was carried out in primary dynamic vacuum $\left(10^{-3} \mathrm{~Pa}\right)$ during all the thermal cycles. The optimized process was selected taking into account previous studies. ${ }^{1,18}$

For the $\mathrm{Al}_{2} \mathrm{O}_{3} / \mathrm{Cu} / \mathrm{Ni} / \mathrm{Cu} / \mathrm{HAYNES}^{\circledR} 214^{\mathrm{TM}}$ system, the process was as follows ${ }^{8}$ : firstly, copper foils $(100 \mu \mathrm{m}$ thick) are polished with a $6 \mu \mathrm{m}$ diamond paste, and oxidized under low oxygen pressure $\left(10^{-3} \mathrm{~Pa}\right)$ at $950{ }^{\circ} \mathrm{C}$ for $0.5 \mathrm{~h}$ to obtain a superficial $\mathrm{Cu}_{2} \mathrm{O}$ film. ${ }^{4} \mathrm{Cu}_{2} \mathrm{O}$ is removed on one of the copper surfaces in contact with nickel. The $\mathrm{Cu}_{2} \mathrm{O}-\mathrm{Cu} / \mathrm{Ni} / \mathrm{Cu}$ multilayer, was placed between alumina and HAYNES ${ }^{\circledR} 214^{\mathrm{TM}}$ substrates, for good metal-ceramic contact. Secondly, the sandwiches were heated $\left(200{ }^{\circ} \mathrm{C} / \mathrm{h}\right)$ and maintained at $1075^{\circ} \mathrm{C}$ for $10 \mathrm{~min}$, and then cooled to room temperature $\left(150^{\circ} \mathrm{C} / \mathrm{h}\right)$. During the entire cycle a minimum low pressure of $1 \mathrm{MPa}$ was applied on the sandwiches and the vacuum in the furnace was maintained at $10^{-3} \mathrm{~Pa}$. At $1075^{\circ} \mathrm{C}$, a eutectic liquid appears at the $\mathrm{Cu}_{2} \mathrm{O}-\mathrm{Cu}$ interface; its amount can be controlled by the oxide growth conditions of the copper foil. This thin molten film produces an intimate contact between copper and alumina and generates, after cooling, a strong bond between metal and ceramic materials. ${ }^{4,6,8}$ 


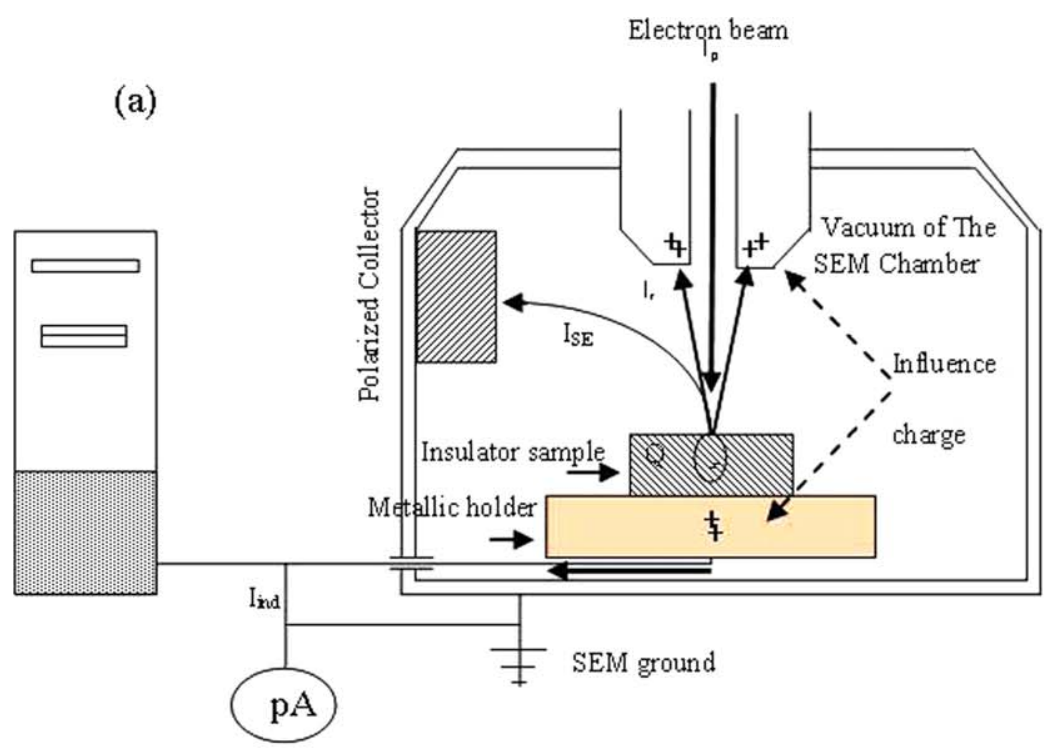

(c)

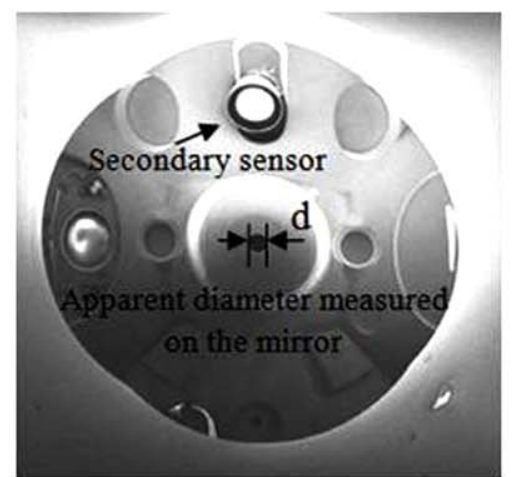

(b)

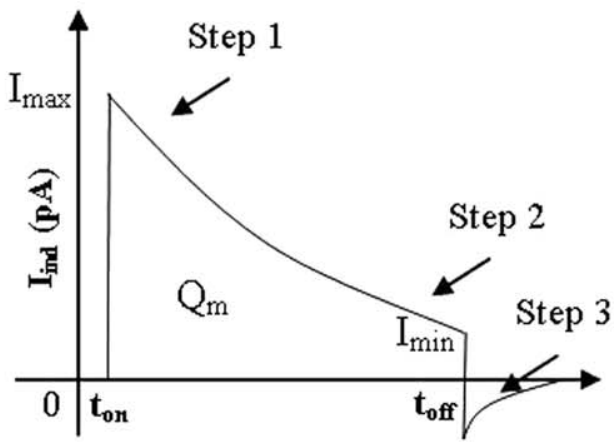

Injection time (ms)

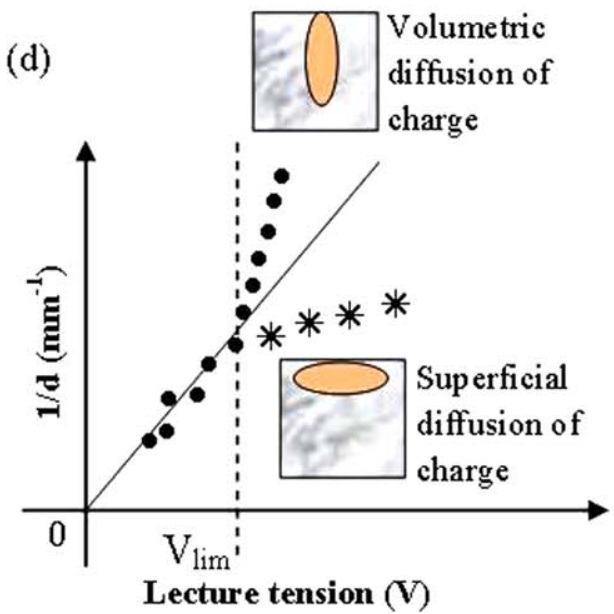

Fig. 2. (a) Schematic experimental set-up for measuring the induced and surface currents; (b) schematic ground current curve; (c) mirror image; (d) mirror curve $1 / d=f(V)$.

\subsection{Characterization techniques}

When an insulating material such as alumina ceramics is bombarded by electrons with sufficiently high energy, electrons can penetrate few atomic layers and generate excitons (electron-hole pairs). These electrons and hole can be recombined or can be trapped on structural defects. In this way, the use of Scanning Electron Microscope (SEM) is interesting to simulate the injection of charges (electrons) and then to observe the trapping of charges. ${ }^{16}$ The Induced Current Method (ICM) ${ }^{17}$ gives the dynamic aspects during the charge injection. On the other hand, the SEMME method gives the capacity of charges to be locally trapped in the insulating materials. The use of both techniques can be applied to any insulating material and allows us to determine the ability of the insulator to trap or to diffuse electric charges.

\subsubsection{Induced Current Method (ICM)}

In our study, the alumina ceramics is bombarded at $25^{\circ} \mathrm{C}$ by electrons, in focused mode, at high voltage $(30 \mathrm{KeV})$ in SEM (LEO 440, Electron Microscopy Ltd., Cambridge, UK) equipped with a beam blanking device to select the irradiation duration (injection time $t_{\mathrm{m}}=100 \mathrm{~ms}$ ), in order to know the total quantity of injected charges $\left(Q_{\mathrm{i}}=100 \mathrm{pC}\right)$ (Fig. 2a).

Any evolution of the total electric charges in the SEM/insulating material system involves a flow of induced charges towards the ground of the SEM. ${ }^{17}$ This evolution is recorded in the form of induced current $I_{\text {inf }}$. This current is measured using a pico-ammeter (Keithley type). The curve $I_{\text {inf }}=f$ (injection time) permits to obtain the total quantity of charges $Q_{\mathrm{m}}$, distributed in the samples (bulk and surface) during the injection:

$Q_{\mathrm{m}}=\int I_{\mathrm{inf}} d t$

The typical evolution of $I_{\mathrm{inf}}=f(t)$ during injection (Fig. 2b) gives information on the different steps of diffusion or trapping of charges present in the insulating sample:

- Step 1 - unsteady step: a decrease in $I_{\text {inf }}$ is observed as a result of the increase in the surface potential, according to trapped charge stabilized just beneath the beam impact point. 
The incident electrons are slowed down and then $I_{\text {inf }}$ decreases continuously.

- Step 2 - steady step: an asymptotic profile is observed. It corresponds to a self-regulating process between slowing of incident electrons, secondary emission, diffusion and trapping of charges.

- Step 3 - after the stop of the electron injection, a depolarization-detrapping step, can be observed. This phenomenon leads to a brutal fall of the current curve and a part of the trapped charges can be brutally re-emitted.

Sometimes this phenomenon of charge relaxations can appear during the electron injection: the influence current $\left(I_{\text {inf }}\right)$ falls brutally, associated with secondary emission.

\subsubsection{Scanning Electron Microscope Mirror Effect (SEMME) method}

The SEMME method ${ }^{16}$ will be performed after the injection step. The observation at lower energy $(V=100-3000 \mathrm{~V})$ of the irradiated zone makes it possible to put in evidence the mirror effect. ${ }^{16,17}$ In fact negative charges $Q_{\mathrm{p}}$ locally trapped and stabilized near to the injection point can induce the deflection of incident electrons: the mirror image is a view of the SEM chamber (Fig. 2c). The quantity $Q_{\mathrm{p}}$ of trapped charges can be deduced from the slope of the linear part of the "mirror" curve $1 / d=f(V)$ (Fig. 2d) according to an electrostatic law, established by Vallayer, ${ }^{16}$ relating the real diameter $d^{\prime}$ of the last output diaphragm and the apparent one, $d$, measured on the mirror image:

$\frac{1}{d}=\frac{4 L}{d^{\prime}} \frac{2 \pi \varepsilon_{0}\left(\varepsilon_{\mathrm{r}}+1\right)}{Q_{\mathrm{p}}} V$

where $L$ is the working distance of the SEM, fixed at $10 \mathrm{~mm} ; d^{\prime}$, the diameter of the last output diaphragm $(5.3 \mathrm{~mm})$; $d$, the apparent diameter measured on the mirror image; $V$, the acceleration potential of the electron beam; $\varepsilon_{\mathrm{r}}$, the permittivity of alumina.

The comparison between $Q_{\mathrm{m}}$, measured by the ICM and $Q_{\mathrm{p}}$, measured by the mirror method, gives information of the charge state in the sample. In fact, if $Q_{\mathrm{p}} / Q_{\mathrm{m}}=1$, the charges are stabilized and trapped near the injection point. However, if $Q_{\mathrm{p}} / Q_{\mathrm{m}}$ tends towards 0 , the charges diffuse in the sample from the injection point.

If the electron beam energy is increased, the mirror curve (Fig. 2d) departs from a straight line beyond a certain tension $V_{\text {lim. }}$. Several authors have shown that the mirror curve curvature is due to a non-punctual charge distribution. ${ }^{16,17,19,20}$

Before testing, each sample i.e. alumina ceramics, $\mathrm{Al}_{2} \mathrm{O}_{3} / \mathrm{Ni} /$ $\mathrm{HAYNES}^{\circledR} 214^{\mathrm{TM}}$ or $\mathrm{Al}_{2} \mathrm{O}_{3} / \mathrm{Cu}_{2} \mathrm{O}-\mathrm{Cu} / \mathrm{Ni} / \mathrm{Cu} / \mathrm{HAYNES}^{\circledR} 214^{\mathrm{TM}}$ joint is annealed $\left(700{ }^{\circ} \mathrm{C}\right.$ for $\left.3 \mathrm{~h}\right)$, in vacuum to avoid the surface contamination. The aim of this annealing is to limit, for the dielectric study, the defects (dislocations ${ }^{21}$ ) and stresses produced by the polishing of the assembly. This annealing also leads to neutralization, total or partial, of the oxygen vacancies by the monovalent or divalent impurities. Four samples of alumina ceramics and multi-materials were analyzed using Induced Current Method (ICM) method and Scanning Electron Microscope Mirror Effect (SEMME) method.

Various parameters can be deduced from ICM and SEMME method (Fig. 2b and d), we selected:

- $I_{\max }$ : initial current that informs on the response of material without any perturbation;

- $Q_{\mathrm{m}}$ : quantity of charges distributed in the sample (ICM);

- $Q_{\mathrm{p}}$ : quantity of charges locally trapped near the injection point (SEMME method).

\section{Results and discussion}

\section{1. $\mathrm{Al}_{2} \mathrm{O}_{3}$ before joining}

As reference, alumina before bonding was studied. Alumina sample received a thermal cycle identical to that used for the assemblies. As reported in Fig. 3a, induced current curves $I_{\text {ind }}=f(t)$, measured for alumina sample before joining, present a high $I_{\max }(785 \pm 55 \mathrm{pA})$ and then, a strongdecrease. The
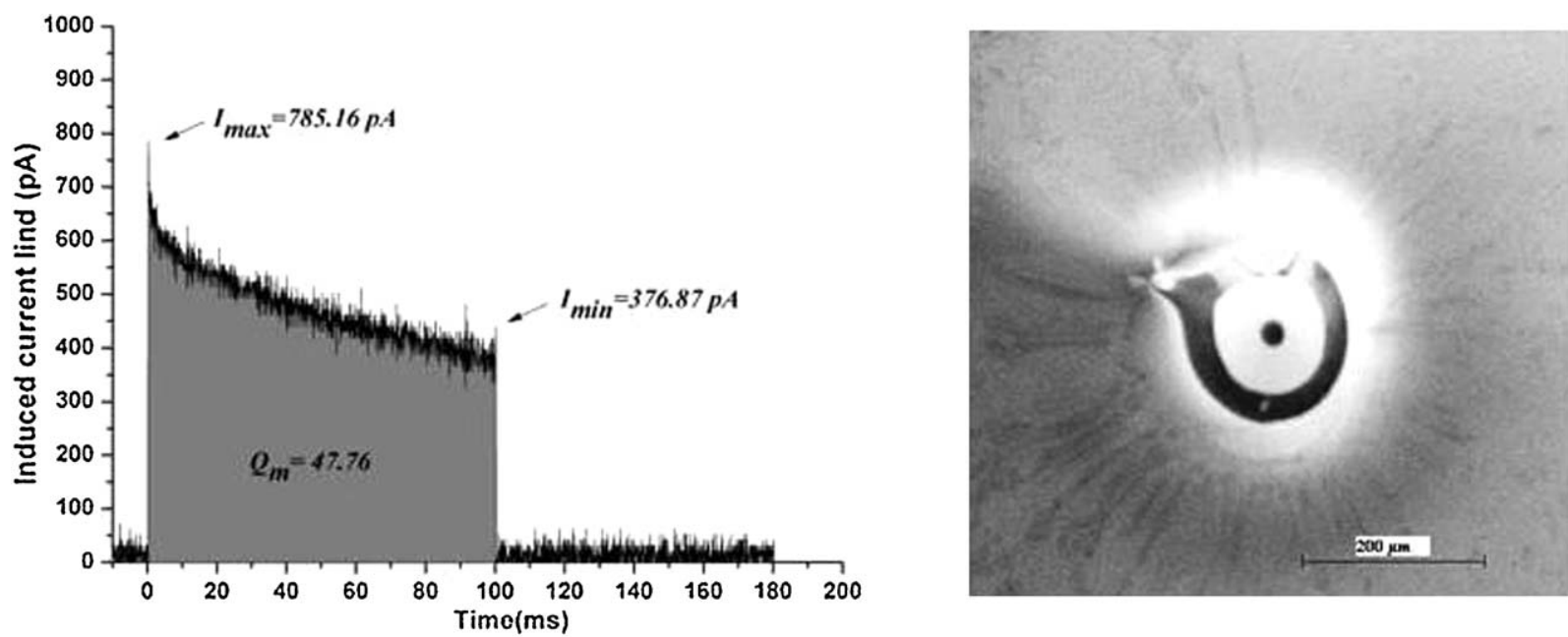

Fig. 3. (a) Evolution of induced currents $I_{\text {ind }}$ during electron irradiation for $\mathrm{Al}_{2} \mathrm{O}_{3}$ ceramics before joining; (b) the mirror image of $\mathrm{Al}_{2} \mathrm{O}_{3}$ ceramics, before joining. 


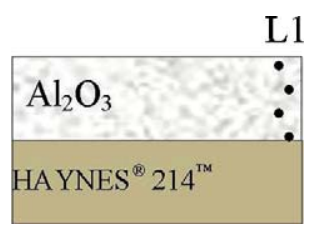

Fig. 4. Schematic representation of the specimen for dielectric measurements.

presence of mirrors (Fig. 3b) confirms that the charges remain concentrated $\left(Q_{\mathrm{p}}=46.1 \mathrm{pC}\right.$ for $100 \mathrm{pC}$ injected electrons and $Q_{\mathrm{m}}=47 \pm 4 \mathrm{pC}$ ), moreover they are stable (tension of disappearance of the mirror for approximately $2200 \mathrm{~V}$ ).

\section{2. $\mathrm{Al}_{2} \mathrm{O}_{3}$ after joining}

The dielectric measurements take place on the free edge of ceramics, close to the interface (L1; Fig. 4). To highlight the influence of the residual stresses (primarily $\sigma_{y y}$ ) and the diffusion of metallic species on the phenomenon of trapping charges, we choose to carry out a filiation of electron injection, in staggered, from the metal-ceramic interface to ceramic bulk. The results of these injections appear in Table 1 for the $\mathrm{Al}_{2} \mathrm{O}_{3} / \mathrm{Ni} / \mathrm{HAYNES}^{\circledR} 214^{\mathrm{TM}}$ system and in Table 2 for the $\mathrm{Al}_{2} \mathrm{O}_{3} / \mathrm{Cu}_{2} \mathrm{O}-\mathrm{Cu} / \mathrm{Ni} / \mathrm{Cu} / \mathrm{HAYNES}^{\circledR} 214^{\mathrm{TM}}$ system.

Two typical examples of $I_{\text {ind }}$ curves are given in Figs. 5 and 6. The curve of Fig. 6a presents a very fast decrease in the current at the first moments of the injection. The post-injection observation shows a mirror effect due to a quantity of trapped charges $Q_{\mathrm{p}}$ localized close to the electronic beam injection point. The asymptotic value of the current is low, corresponding to behaviour of trapping-localization of the charges. The curve of Fig. 5a is very different from the first. During the electron injection, a phenomenon of charge relaxation occurs, accompanied by a brutal emission of secondary electrons, generally due to the local saturation of the traps. After each injection, an observation with low tension (starting from $200 \mathrm{~V}$ ) of the irradiated zone is carried out. The observation of mirrors is frequent and indicates that the charges are localized in the vicinity of the injection point. Far from the interface $(>100 \mu \mathrm{m})$, the majority of the electron injections lead to circular mirrors. In certain cases, in the vicinity of the interface $(50 \mu \mathrm{m})$, they take an elliptic form (Figs. 5b and $6 \mathrm{~b}$ ), with the large axis of the ellipse forming with the interface an angle of $35-40^{\circ}$. Let us note that this angle corresponds to the angle observed for the propagation of cracks (Fig. 7) related to the residual stress field close to the metal $/ \mathrm{Al}_{2} \mathrm{O}_{3}$ interface. Consequently, in the vicinity of the interface, an anisotropic trapped charge distribution is obvious. ${ }^{17}$

These mirrors could be measured what made it possible to determine the quantities $Q_{\mathrm{p}}$ of charges remained locally trapped after injection. The mirrors were stable until a tension from 2 to $2.4 \mathrm{kV}$.

Until a lecture potential $V_{\text {lim }}$ of approximately $\sim 600 \mathrm{~V}$, the $1 / d$ ratio follows a law of proportionality with the lecture potential (Fig. 8) and allows the calculation of the quantity $Q_{\mathrm{p}}$ of trapped charges. Then, the mirror is stretched and becomes more or less deformed; the slope of the $1 / d=f(V)$ curve decreases, indicating that the charges spread out, laterally. ${ }^{16,17,19}$

Table 1

Characteristic parameters deduced from ICM for $\mathrm{Al}_{2} \mathrm{O}_{3} / \mathrm{Ni} / \mathrm{HAYNES}^{\circledR} 214^{\mathrm{TM}}$ joint.

\begin{tabular}{|c|c|c|c|c|c|}
\hline Distance from interface $(\mu \mathrm{m})$ & $I_{\max }(\mathrm{pA})$ & $Q_{\mathrm{m}}(\mathrm{pC})$ & $Q_{\mathrm{p}}(\mathrm{pC})$ & $Q_{\mathrm{p}} / Q_{\mathrm{m}}$ & Relaxations \\
\hline Before joining & 942.187 & 47.65 & 46.1 & 0.967 & No \\
\hline \multicolumn{6}{|l|}{ After joining } \\
\hline 0 & 879.37 & 69.7 & 35.5 & 0.509 & Yes \\
\hline 50 & 750.34 & 26.16 & 2.96 & 0.113 & No \\
\hline 100 & 832.44 & 29.9 & 0 & - & - \\
\hline 140 & 856.34 & 26.8 & 0 & - & - \\
\hline 250 & 829.43 & 26.1 & 6.9 & 0.264 & No \\
\hline 500 & 789.34 & 21.2 & 10.5 & 0.495 & No \\
\hline 1000 & 709.4 & 38.9 & 15.2 & 0.391 & No \\
\hline
\end{tabular}

$Q_{\mathrm{p}}=0$ corresponds to the absence of mirror image due to the diffusion of charges.

Table 2

Characteristic parameters deduced from ICM for $\mathrm{Al}_{2} \mathrm{O}_{3} / \mathrm{Cu}_{2} \mathrm{O}-\mathrm{Cu} / \mathrm{Ni} / \mathrm{Cu} / \mathrm{HAYNES}^{\circledR} 214^{\mathrm{TM}}$ joint.

\begin{tabular}{|c|c|c|c|c|c|}
\hline Distance from interface $(\mu \mathrm{m})$ & $I_{\max }(\mathrm{pA})$ & $Q_{\mathrm{m}}(\mathrm{pC})$ & $Q_{\mathrm{p}}(\mathrm{pC})$ & $Q_{\mathrm{p}} / Q_{\mathrm{m}}$ & Relaxations \\
\hline Before joining & 942.187 & 47.65 & 46.1 & 0.967 & No \\
\hline \multicolumn{6}{|l|}{ After joining } \\
\hline 20 & 822.43 & 58.2 & 37.5 & 0.644 & Yes \\
\hline 45 & 788.33 & 29.12 & 0 & - & - \\
\hline 80 & 790.45 & 28.3 & 0 & - & - \\
\hline 120 & 844.21 & 26.1 & 0 & - & - \\
\hline 250 & 756.21 & 26.4 & 12.3 & 0.465 & No \\
\hline 1000 & 734.12 & 22.1 & 14.45 & 0.653 & No \\
\hline
\end{tabular}

$Q_{\mathrm{p}}=0$ corresponds to the absence of mirror image due to the diffusion of charges. 


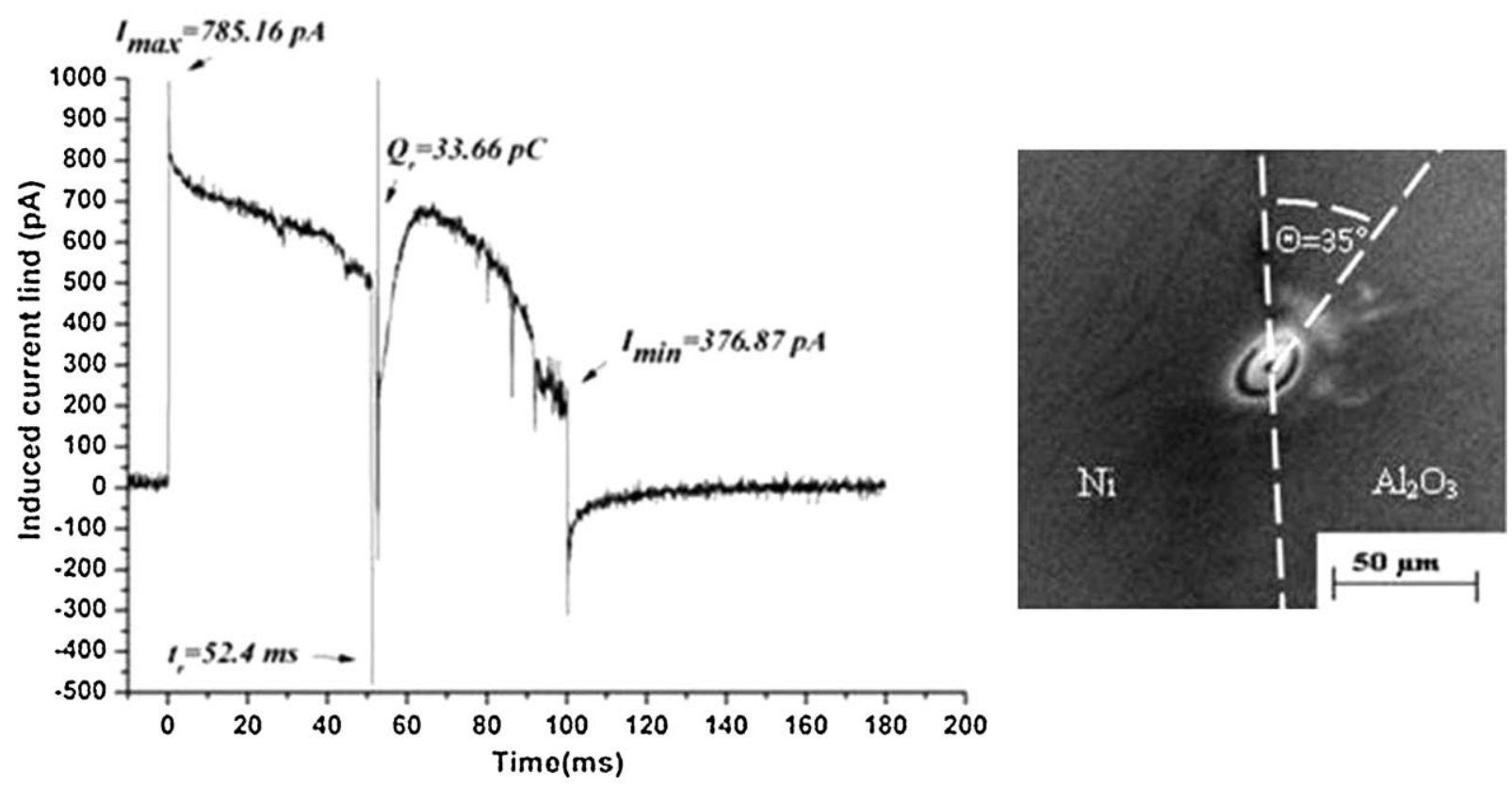

Fig. 5. (a) Typical $I_{\text {ind }}(t)$ plots for injections at the $\mathrm{Ni} / \mathrm{Al}_{2} \mathrm{O}_{3}$ interface: behaviour of periodic secondary electronic relaxation on the level of the interface. (b) The corresponding mirror image $\left(\mathrm{Al}_{2} \mathrm{O}_{3} / \mathrm{Ni} / \mathrm{HAYNES}^{\circledR} 214^{\mathrm{TM}}\right.$ system).

\subsubsection{Correlation between trapping of electric charges and apparent-toughness}

Fig. 9 shows the evolution of alumina toughness from the metal-ceramic interface. Apparent-toughness is very weak level near the interface and then increases to be maxima to $150-200 \mu \mathrm{m}$. It then tends to the toughness of the starting alumina (5.8 $\left.\mathrm{MPa} \mathrm{m}^{1 / 2}\right)$, away from the interface.

Three zones can be highlighted (Fig. 9), related to trapping of charges (Tables 1 and 2):
- Zone 1 (0 to about $50 \mu \mathrm{m})$ : toughness is very low and, parallel, $Q_{\mathrm{p}}$ and $Q_{\mathrm{m}}$ are high (respectively $35-40 \mathrm{pC}$ and $58-70 \mathrm{pC}$ for $100 \mathrm{pC}$ injected electrons). The trapping is localized which leads to a lowering in toughness.

- Zone 2 (50 to $150-200 \mu \mathrm{m})$ : toughness increases sharply beyond the toughness of alumina before assembly $\left(5.8 \mathrm{MPam}^{1 / 2}\right)$ while $Q_{\mathrm{p}}$ is zero: the charges diffuse throughout the ceramics.

- Zone 3 (over 150-200 $\mu \mathrm{m}$ ): after reaching a maximum, the toughness gradually decreases and $Q_{\mathrm{p}}$ increases. $Q_{\mathrm{m}}$ remains

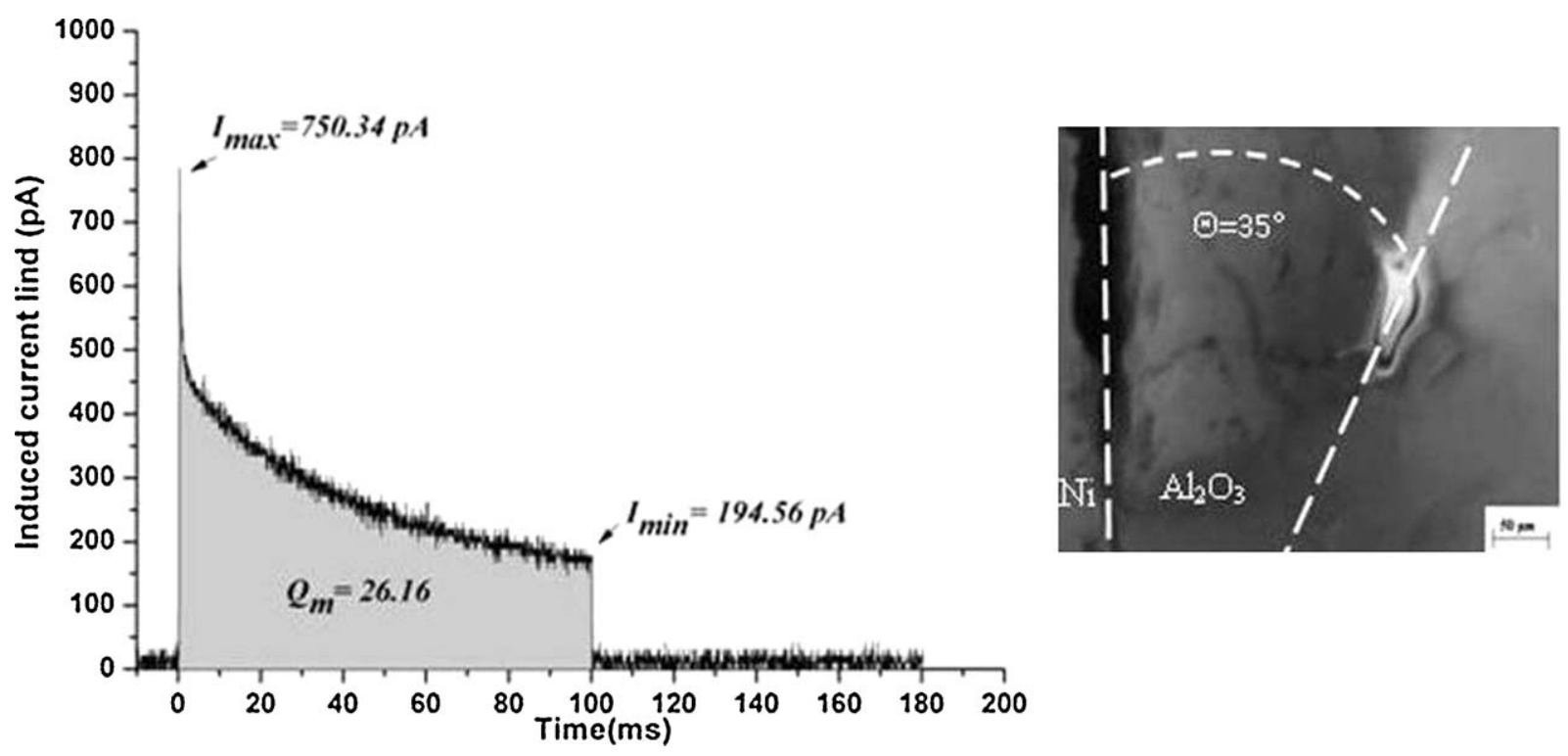

Fig. 6. (a) Typical $I_{\text {ind }}(t)$ plots for injections at $\sim 50 \mu \mathrm{m}$ from the $\mathrm{Ni} / \mathrm{Al}_{2} \mathrm{O}_{3}$ interface: behaviour of trapping-localization of charges; (b) the corresponding mirror image $\left(\mathrm{Al}_{2} \mathrm{O}_{3} / \mathrm{Ni} / \mathrm{HAYNES}^{\circledR} 214^{\mathrm{TM}}\right.$ system). 

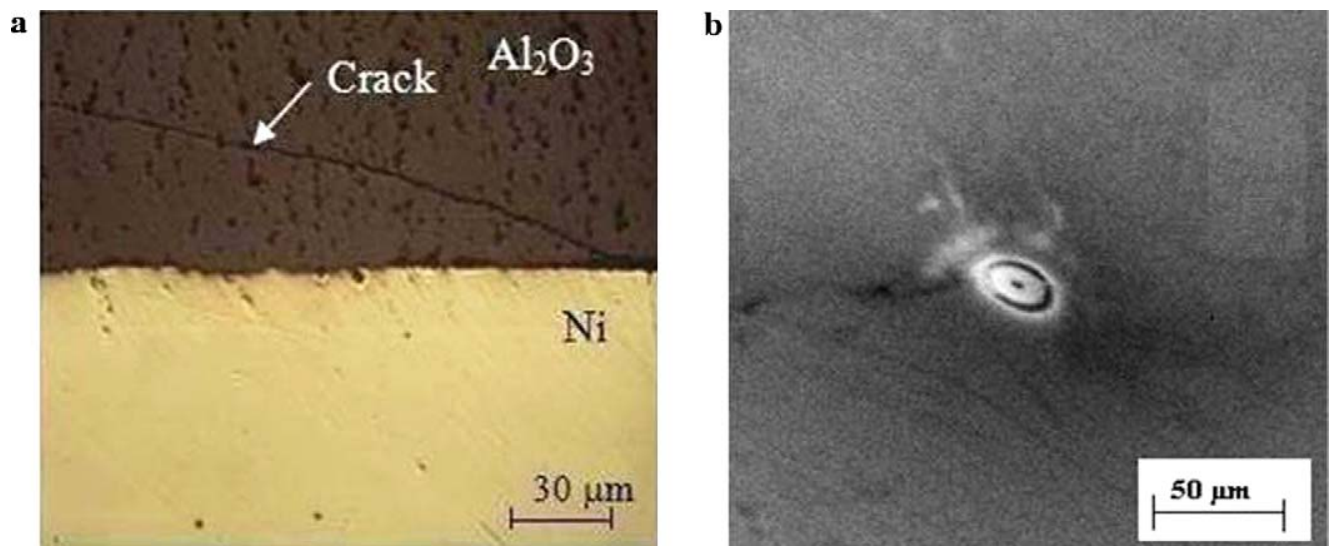

Fig. 7. Crack propagation in alumina ceramic in the $\mathrm{Al}_{2} \mathrm{O}_{3} / \mathrm{Ni} / \mathrm{HAYNES}^{\circledR} 214^{\mathrm{TM}}$ system after joining process. It will be noted that the angle of the crack with the interface is close $\left(35-45^{\circ}\right)$ to that observed for the elliptic mirror, following in that the stress field lines. ${ }^{1,3}$ (a) Optical image of polished cross-section perpendicular to the interfaces; (b) typical elliptic mirror observed after injection near to the interface $(\sim<50 \mu \mathrm{m})$.

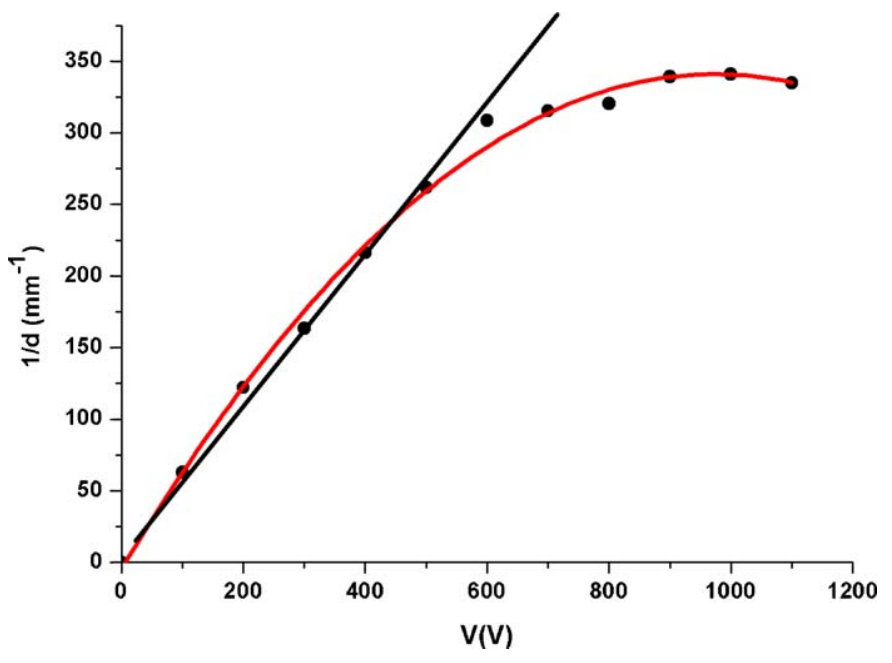

Fig. 8. Evolution of the ratio $1 / d$ ratio vs lecture potential, after $100 \mathrm{pC}$ injected electrons on the surface of alumina near the interface $(\sim 90 \mu \mathrm{m})$ for the $\mathrm{Al}_{2} \mathrm{O}_{3} / \mathrm{Ni} /$ nickel alloy system.

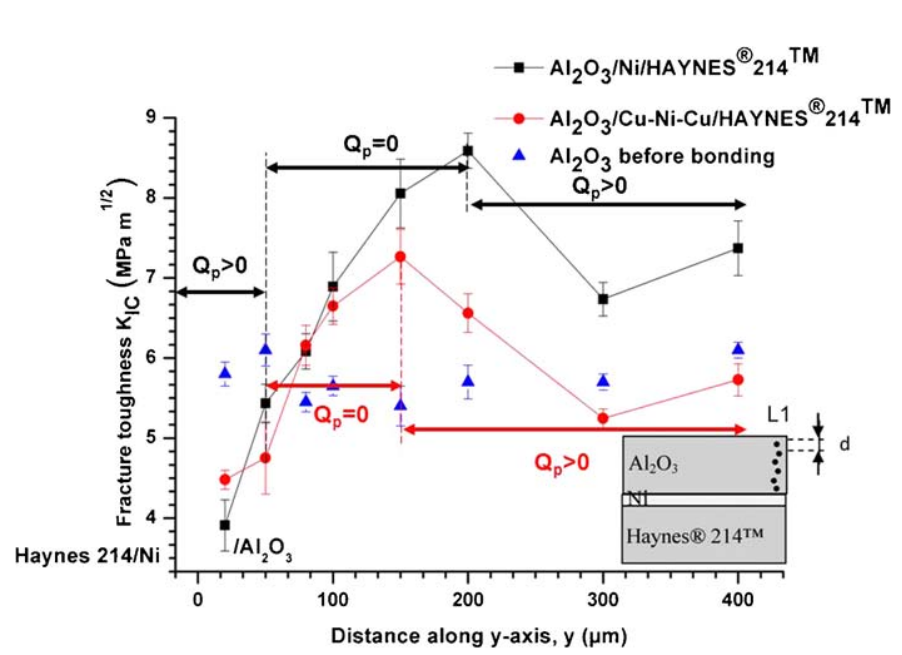

Fig. 9. Evolution of alumina apparent-toughness for both $\mathrm{Al}_{2} \mathrm{O}_{3} / \mathrm{Ni} / \mathrm{HAYNES}^{\circledR} 214^{\mathrm{TM}}$ and $\mathrm{Al}_{2} \mathrm{O}_{3} / \mathrm{Cu}_{2} \mathrm{O}-\mathrm{Cu} / \mathrm{Ni} / \mathrm{Cu} / \mathrm{HAYNES}^{\circledR} 214^{\mathrm{TM}}$ systems. relatively constant (Tables 1 and 2). So $Q_{\mathrm{p}}$ (not $Q_{\mathrm{m}}$ ) is the quantity most appropriate for understanding the evolution of toughness.

However, a question arises: how to explain the large increase in toughness (reinforcing effects) associated exactly to the nullification of $Q_{\mathrm{p}}$ (zone 2)?

The most likely hypothesis, usually advanced for this type of reinforcement, ${ }^{22}$ is the formation of a micro-cracking due to residual stresses developed in the assembly. These microcracks are favourable to the diffusion of charges proved by the $Q_{\mathrm{p}}$ decrease. ${ }^{23}$ Beyond this zone 2 , the micro-cracking disappears and the energetic potential increases gradually leading to a new decrease in toughness (zone 3). $Q_{\mathrm{p}}, Q_{\mathrm{m}}$ and $K_{\mathrm{IC}}$ tend far from the interface to their values before bonding.

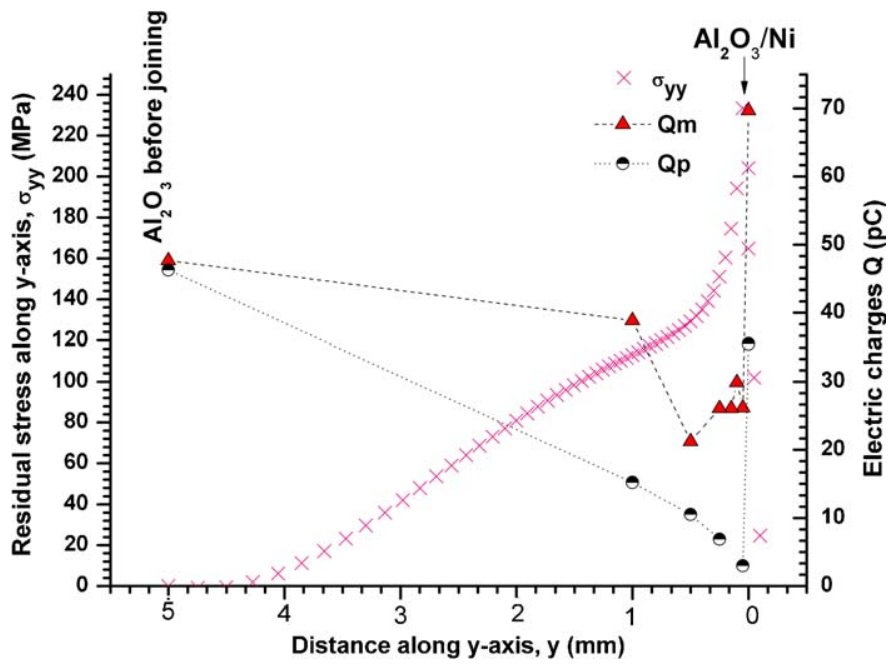

Fig. 10. (a) Evolution of the quantities of charges $Q_{\mathrm{m}}$ and $Q_{\mathrm{p}}$ and normal stress $\sigma_{y y}$ measured on the free edge (L1), vs distance $y$ from the metal-ceramic interface. (b) Residual stresses determined by Finite Element Analysis (FEA) ${ }^{1,3}$ $\left(\mathrm{Al}_{2} \mathrm{O}_{3} / \mathrm{Ni} / \mathrm{HAYNES}^{\circledR} 214^{\mathrm{TM}}\right.$ system). 

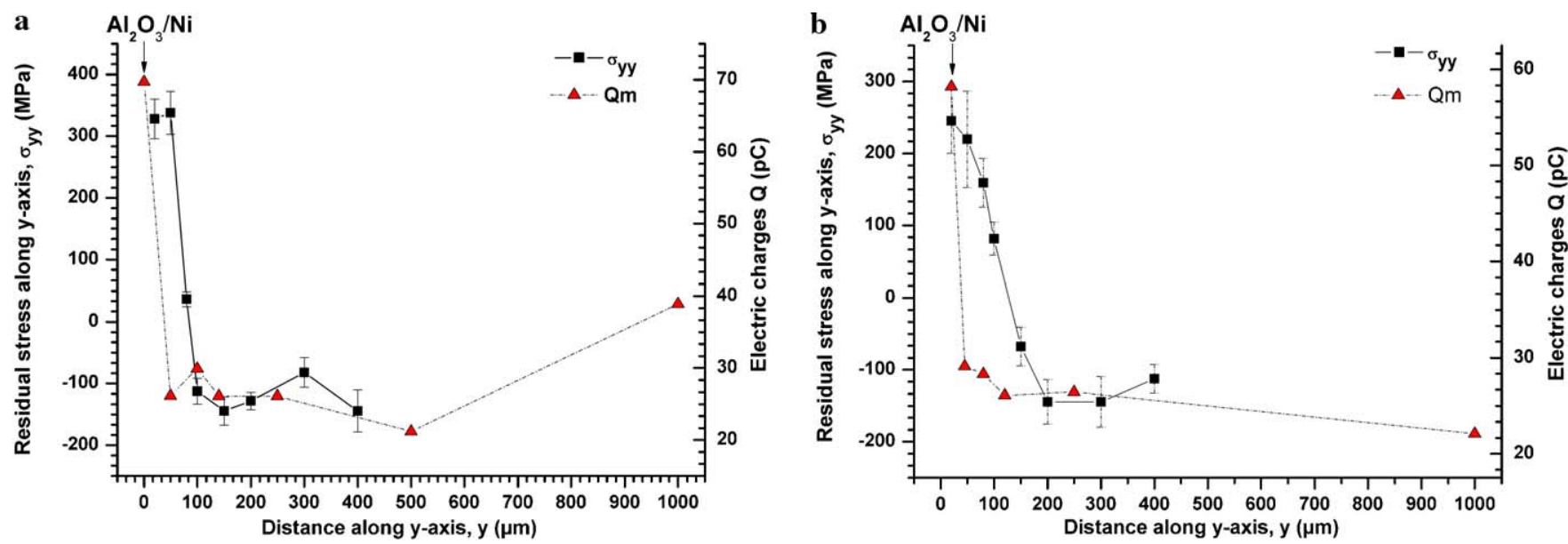

Fig. 11. Comparing the quantity of influence charges $Q_{\mathrm{m}}$ and residual stress estimated by Vickers indentation in both types of assemblies: (a) $\mathrm{Al}_{2} \mathrm{O}_{3} / \mathrm{Ni} / \mathrm{HAYNES}^{\circledR} 214^{\mathrm{TM}}$, (b) $\mathrm{Al}_{2} \mathrm{O}_{3} / \mathrm{Cu}_{2} \mathrm{O}-\mathrm{Cu} / \mathrm{Ni} / \mathrm{Cu} / \mathrm{HAYNES}^{\circledR} 214^{\mathrm{TM}}$.

\subsubsection{Correlation between trapping of electric charges and residual stresses}

The results of the quantities of influence charges $Q_{\mathrm{m}}$ and charges locally trapped $Q_{\mathrm{p}}$ for the $\mathrm{Al}_{2} \mathrm{O}_{3} / \mathrm{Ni} /$ nickel alloy system, were compared with those of the residual stresses determined by Finite Element Analysis (FEA) ${ }^{1,3}$ (Fig. 10).

A strong regular decrease of tensile stresses was observed (let us recall that in fact tensile stresses are harmful) and, in parallel, $Q_{\mathrm{m}}$ and $Q_{\mathrm{p}}$ decrease until reaching a minimum, then increase towards their values for alumina before junction. This difference in evolution can be explained by the fact why FEA simulation does not take into account the evolution of the properties of ceramics in the vicinity of the interface, as shown previously (Fig. 9).

Otherwise, Vickers indentation technique makes possible to consider the residual stresses in the same area as that corresponding to dielectric measurements. ${ }^{3,8}$

For the two systems, the evolution of the quantity of charges $Q_{\mathrm{m}}$ vs the distance to the interface (Fig. 11 and Tables 1 and 2) shows:

- A similar evolution for $Q_{\mathrm{m}}$ and tensile residual stresses measured by Vickers indentation.

- The quantities of charges $\left(Q_{\mathrm{m}}\right.$ or $\left.Q_{\mathrm{p}}\right)$ stored in alumina are very strongly increased close to the interface (Tables 1 and 2).

- The strong fall of $Q_{\mathrm{m}}$ and $Q_{\mathrm{p}}$, below approximately $100 \mu \mathrm{m}$ far from the interface, is related to the fall of stresses observed by indentation.

- For the $\mathrm{Al}_{2} \mathrm{O}_{3} / \mathrm{Ni} /$ nickel alloy system, $Q_{\mathrm{m}}$ becomes again higher at long distance $(1 \mathrm{~mm})$ while tending towards the value of alumina, before bonding. This tendency is slower for the system $\mathrm{Al}_{2} \mathrm{O}_{3} / \mathrm{Cu}_{2} \mathrm{O}-\mathrm{Cu} / \mathrm{Ni} / \mathrm{Cu} / \mathrm{HAYNES}^{\circledR} 214^{\mathrm{TM}}$.

- The $Q_{\mathrm{p}} / Q_{\mathrm{m}}$ ratio, close to 1 for alumina before bonding, is low or zero in areas of high tensile stresses (Tables 1 and 2). This shows that tensile stresses favour the mobility of the charges starting from the injection point of electrons.

These results are to be compared to those obtained by in situ electron injection on alumina subjected to bending stresses ${ }^{24}$ : in fact mechanical load influences the capacity of material to trap and/or to diffuse electric charges. The interpretation which can be given was developed in [24]. Under mechanical loading, the distortions of the lattice can allow a trapping of charges leading to storage of polarization energy. This energy can be sufficient to create dislocations which appear in the alumina lattice, thus creating new sites of trapping. ${ }^{25}$ These created dislocations are mobile and subjected to an electric field. Consequently, an increase in the trapping of the charges occurs but these charges do not remain localized (mirror not very stable and $Q_{\mathrm{p}} / Q_{\mathrm{m}}<1$ ).

Let us note that these measurements are sensitive as well to the stress field as with the effect of diffusion of nickel (Ni) or copper $(\mathrm{Cu})$ and then, these two factors favour the trapping and/or the mobility of the charges. Lastly, according to our results it is obvious that the $\mathrm{Al}_{2} \mathrm{O}_{3} / \mathrm{Cu} / \mathrm{Ni} / \mathrm{Cu} / \mathrm{HAYNES}^{\circledR} 214^{\mathrm{TM}}$ system is less stressed than the $\mathrm{Al}_{2} \mathrm{O}_{3} / \mathrm{Ni} / \mathrm{HAYNES}^{\circledR} 214^{\mathrm{TM}}$ system (weaker $Q_{\mathrm{m}}$ ), which induces mechanical properties of the assembly more favourable (shearing, bending, interfacial fracture energy, toughness). ${ }^{3,8}$

\section{Conclusions}

The two complementary techniques: Induced current Method (ICM) and Scanning Electron Microscope Mirror Effect (SEMME) method are the non-destructive technique developed for insulator characterization for the study of charging properties of ceramics. Knowing that localized trapped charges in ceramics is a source of damage, the correlation between residual stress intensity, ceramic apparent-toughness and ability to trap charges near the interface was demonstrated. In summary, the following points can be retained:

1. A residual stress field appears close to the metal-ceramic interface, in particular, due to thermal expansion mismatch between metal and ceramics. The comparison between the various methods (XRD, ${ }^{1,8}$ FEA, ${ }^{1}$ and $\mathrm{VIF}^{3,8}$ ) and estimations of the stress field in ceramics, reveals a global tendency, to pass from traction (near interface) towards compression (medium of ceramics), before cancelling itself (far from the 
interface); but only VIF and SEMME, by their good spatial resolution, demonstrate wide variations of stresses in sub-layer.

2. It is confirmed that the mechanical and dielectric properties of ceramics are significantly altered in the vicinity of metal-ceramic interface. These changes, due to the process, are related both to thermo-mechanical stresses and diffusion in ceramics of metallic species.

3. The results of Vickers indentation mainly revealed us that the apparent-toughness of ceramics falls in the vicinity of the metal-ceramic interface what leads to the embrittlement of ceramics. This fall can be explained by the existence of the stress field and/or the diffusion of the metals $(\mathrm{Ni}, \mathrm{Cu})$ in alumina. Indeed, the developed stresses will create a distortion of the crystal lattice, being able to play the role of sites of charge trapping, then creation of dislocations. ${ }^{12,25}$

4. The mirror method made it possible to highlight the role played by the residual stresses in diffusion of electric charges in metal-ceramic assemblies. The residual stress field close to the interface modifies significantly the response of ceramics to the charge injection.

5. Toughness and breakdown being dependent, ${ }^{14,26}$ a fall of resistance to the breakdown of ceramics in the vicinity of the junction can be expected.

6. Finally, we show that SEMME characterization can be a good method for study of residual stress and changes in properties of materials developed in metal/ceramic joints. However, for a careful estimation of the residual stresses alone, SEMME method and ICM should be calibrated using previously described protocols ${ }^{24}$ to avoid the superposition of several phenomena (diffusion, stresses, micro-cracking, etc.).

\section{Acknowledgements}

Special thanks are due to the IFP Energies nouvelles, for providing the financial resources. The authors thank Denyse Juvé from École Centrale de Lyon for technical collaboration for the SEM equipment and for helpful discussions.

\section{References}

1. Hattali ML, Valette S, Ropital S, Mesrati N, Tréheux D. Calculation and experimental determinations of the residual stress distribution in alumina/Ni/alumina and alumina/Ni/nickel alloy systems. J Mater $S c i$ 2010;45(15):4133-40.

2. Hattali ML, Valette S, Ropital S, Mesrati N, Tréheux D. Study of SiC-nickel alloy bonding for high temperature applications. J Eur Ceram Soc 2009;29:813-9.

3. Hattali ML, Valette S, Ropital S, Mesrati N, Tréheux D. Effect of thermal residual stresses on the strength for both alumina/ $\mathrm{Ni} /$ alumina and alumina/Ni/nickel alloy bimaterials. J Mater Sci 2009;44:3198-210.
4. Beraud C, Courbière M, Esnouf C, Juvé D, Tréheux D. Study of copper-alumina bonding. J Mater Sci 1989;24:4545-54.

5. Ning H, Ma J, Huang F, Wang Y, Li Q, Li X. Preoxidation of the Cu layer in direct bonding technology. Appl Surf Sci 2003;211:250-8.

6. Burgess JF, Neugebauer CA, Flanagan G. Direct bonding of metals to ceramics by the gas-metal eutectic method. $J$ Electrochem Soc 1975;122(5):688-90.

7. Sun YS, Driscoll JC. A new hybrid power technique utilizing a direct copper to ceramic bond. IEEE Trans Electron Devices 1976;96:1-967.

8. Hattali ML, Valette S, Ropital F, Mesrati N, Tréheux D. Interfacial behavior on $\mathrm{Al}_{2} \mathrm{O}_{3} /$ Haynes $^{\circledR} 214^{\mathrm{TM}}$ joints fabricated by solid state bonding technique with $\mathrm{Ni}$ or $\mathrm{Cu}-\mathrm{Ni}-\mathrm{Cu}$ interlayers. J Eur Ceram Soc, in press.

9. Tréheux D, Fayeulle S, Guipont V, Jacquemin JP. In: Bellosi A, et al., editors. Interfacial science in ceramic joining. Kluwer Academic Publishers; 1989. p. 311-8.

10. Fayeulle S, Berroug A, Hamzaoui B, Tréheux D. Role of dielectric properties in the tribological behaviour of insulators. Wear 1993;906:162-4.

11. Guerret-Piecourt C, Vallayer J, Tréheux D. Limitation induced by electrical charges effects on micromechanisms. Wear 2003;254(10):950.

12. Bonnelle C, Blaise G, Le Gressus C, Tréheux D. Les isolants, physique de la localisation des porteurs de charge. Application aux phénomènes d'endommagement. Lavoisier, Paris: Editions Tech et Doc; 2010, ISBN 978-2-7430-1229-8.

13. Le Gressus C, Blaise G. Breakdown phenomena related to trapping/detrapping processes in wide band-gap insulators. IEEE Trans Electr Insul 1992;27:472-81.

14. Haddour L, Mesrati N, Goeuriot D, Tréheux D. Relationships between microstructure, mechanical and dielectric properties of different alumina materials. J Eur Ceram Soc 2008;29:2747.

15. Blaise G, Le GressusF C. Mise en évidence d'un claquage des isolants associé à la déstabilisation d'une charge d'espace localisée. $C R$ Acad Sci 1992;:t314:1017-24.

16. Vallayer B, Blaise G, Tréheux D. Space charge measurement in a dielectric material after irradiation with a $30 \mathrm{kV}$ electron beam application to single-crystal oxide trapping properties. Rev Sci Instrum 1999;70(7): 3102-12.

17. Temga T, Juvé D, Tréheux D, Guerret-Piecourt C, Jardin C. Conduction and trapping of electric charges in an anisotropic material after irradiation with an e-beam: application to $\mathrm{TiO}_{2}$ single crystal. Nucl Instrum Methods Phys Res B 2006;245(2):519.

18. Lourdin P, Juvé D, Tréheux D. Nickel-alumina bonds: mechanical properties related to interfacial chemistry. J Eur Ceram Soc 1996;16(7):745.

19. Ghorbel N, Kallel A, Damamme G, Renoud R, Fakhfakh Z. Analytical description of mirror plot in insulating target. Eur Phys $J$ Appl Phys 2006;36:271.

20. Damamme G, Le Gressus C, De Reggi AS. Space charge characterization for the 21st century. IEEE Trans Dielectr Electr Insul 1997;4:558.

21. Hockey BJ. Plastic deformation of aluminium oxide by indentation and abrasion. J Am Ceram Soc 1971;54(5):223.

22. Simpson LA. Effect of microstructure on measurement of grain size dependence of fracture energy in $\mathrm{Al}_{2} \mathrm{O}_{3} . J$ Am Ceram Soc 1973;56(1):7-11.

23. Meyza X, Goeuriot D, Liebault J, Thevenot F, Juvé D, Tréheux D. Thermal shock on an alumina: influence on mechanical and dielectric properties. Le Vide: science, technique et application 2001;160. Numéro spécial.

24. Juvé D, Tréheux D, Bigarré J, Hourquebie P.CSC'3. Le Vide: science, techniques et applications 2001;287:463.

25. Zong X-F, Shen C-F, Liu S, Chen Y, Zhang R. Model for radiation induced degradation of $\alpha \mathrm{Al}_{2} \mathrm{O}_{3}$ crystals. Phys Rev B 1996;54(1):139-43.

26. Fothergill JC. Filamentary electromechanical breakdown. IEEE Trans Electr Insul 1991;26(6):1124-9. 